\title{
Influence of Compensation, Job Characteristics and Leadership Style Through Motivation to Employee Performance
}

\section{Muhammad Dominique Mendoza, Harmein Nasution, and Nazaruddin Matondang}

Management Postgraduate Program of North Sumatera University

\section{Abstract}

The purpose of this study is to find out and analyze the impact of Compensation, Work Characteristics and Leadership Style on Employee Motivation and Performance at the northern region of Adolina plantation PT. Perkebunan Nusantara IV. Samples taken in this study were 103 people. Data were collected through questionnaire and tested using validity and reliability tests; data must fulfill the classical assumption of test element, then the data were tested using path analysis. This study concludes that there is a significant influence of Compensation to Motivation, an influence of Job

Received: 29 August 2018 Accepted: 18 September 2018 Published: 11 November 2018

Publishing services provided by Knowledge

(c) Muhammad Dominique Mendoza et al. This article is distributed under the terms of the Creative Commons

Attribution License, which permits unrestricted use and redistribution provided that the original author and source are credited.

Selection and Peer-review under the responsibility of the ICOI-2018 Conference Committee.

\section{G OPEN ACCESS} Characteristics on Employee Motivation, there is no significant influence of Leadership Style on Employee Motivation, there is an influence of Compensation to Performance, there is significant influence of Work Characteristics to Employee Performance, and there is no significant influence of Leadership Style on Employee Performance, there is an influence of Motivation to Employee Performance at Adolina Business Unit of PT. Perkebunan Nusantara IV.

Keywords: compensation, job characteristics, leadership style, motivation, employee performance

\section{Introduction}

Goals set by the company will be achieved if the company has a good level of employee performance. Performance defines as a result of work in quality and quantity achieved by an employee in performing their job in accordance with the responsibilities given to him. Handoko (2011) states that if employees perceive inadequate compensation, then their performance, motivation and job satisfaction will drop dramatically.

Besides job characteristics, the performance of an employee is also determined by the leadership style applied by the respective company leaders. Improving the performance of employees in an organization cannot be separated from the role of leaders in the organization, leadership is the key in management that plays an important and strategic role in the survival of a company (Hidayati et al., 2015). 
Whether it is realized or not, job characteristics and leadership style used by leaders in leading the employees, cannot be separated from the motivation made by the leadership before doing the work.

\section{Literature Review}

\subsection{Compensation}

According to Hasibuan (2014), compensation is all of employee income in the form of money and goods which received by employee directly or indirectly in return for all of the work given. Moreover, according to Handoko (2011), compensation is everything that received by employee as a compensation for the services they provide.

\subsection{Job characteristics}

Robin and Coulter (2010) states that job characteristics are an internal aspect of a job that refers to the content and conditions of the job. Therefore, job characteristics is the trait and tasks that includes responsibility, tasks and level of satisfaction derived from the work itself.

\subsection{Leadership style}

According to Sutrisno (2010), leadership is the ability to influence others, through direct or indirect communication with the intent to motivate people to be understanding, conscious, and happy to follow the will of the leader, and the leadership style is a way that the leaders use in interacting with their employee.

\subsection{Motivation}

According to Manullang (2010), motivation is action done by a manager in giving inspiration, to support employee to take measure, to encourage employee to be enthusiastic and achieve the desired result. 


\subsection{Employee performance}

Mathis and Jackson (2012) states that performance basically is what employee do or do not do. Employee performance is what affects how much they contribute to the organization that includes output quantity, output quality, output periods, attendance and cooperative attitude.

\subsection{Hypothesis}

In accordance with the aforementioned explanation, the hypothesis of this study can be defined as:

1. Compensation has effect on motivation

2. Job characteristics has effect on motivation

3. Leadership style has effect on motivation

4. Compensation has effect on employee performance

5. Job characteristics has effect on employee performance

6. Leadership style has effect on employee performance

7. Compensation through motivation has effect on employee performance

8. Job characteristics through motivation has effect on employee performance

9. Leadership style through motivation has effect on employee performance

\section{Research Methods}

This study is conducted at Adolina business unit of PT Perkebunan Nusantara IV. The type of research used in this study is correlational research, which aims to analyze and test the causal relationship between independent and dependent variables.

The population in this research is all employees of north region of Adolina unit that is 103 people, this study takes the entire population as sample (census).

Analysis technique used in this research is Path Analysis which operated through SPSS program. This analysis is used to determine how much influence a variable to other variables, both direct influence and joint influence (joint effect). 


\subsection{Measured variables}

The indicator and measurement scale are used to facilitate this study. The analysis and discussion of variables used in this study are as follows:

\subsubsection{Compensation $\left(X_{1}\right)$}

Compensation is something that received by employee as a recompense of their contribution and services to the company (indicator: salary, allowance, bonus, health insurance, praise of work achievement, award for achievement).

\subsubsection{Job characteristics $\left(X_{2}\right)$}

Job characteristics is an internal aspect of a job that refers to the content and conditions of the job (indicator: autonomy, job variation, identity assignment, task significance, feedback).

\subsubsection{Leadership style $\left(X_{3}\right)$}

Leadership style is an attempt by a leader to influence a person's or a group's behavior that aims to achieve the individual or shared goals of the organization (indicator: briefing, communication, decision-making, motivation, consultative, participation).

\subsubsection{Motivation $\left(Y_{1}\right)$}

Motivation is strength, encouragement, need, passion, or any psychological mechanism that encourage a person or group to achieve certain accomplishments in accordance with what is desired (indicator: status, interpersonal relationship with superior and subordinate, supervision, workability, working condition).

\subsubsection{Employee performance $\left(Y_{2}\right)$}

Employee performance is the results of work in quality and quantity that achieved by an employee in performing tasks in accordance with their responsibilities (indicator: knowledge of work, attitude, initiative, quality of work, cooperation, creativity, reliable). 


\subsection{Data collection technique}

The data in this study consists of primary and secondary data. Data collection technique used to obtain the data is as follows:

\subsubsection{Questionnaire}

By distributing a list of questions to the respondents, where respondents choose one of the provided answers.

\subsubsection{Interview}

By interviewing the employee that provides concerned information and data.

\subsubsection{Documentation study}

Documentation study is obtained through materials, documents, and literatures which have been published in libraries.

\subsection{Data quality test}

1. Validity Test

2. Reliability Test

3. Classic Assumption Test

4. Normality Test

5. Multicollinearity Test

6. Heteroscedasticity Test

\subsection{Data analysis technique}




\subsubsection{Coefficient of determination}

Coefficient of Determination is the square of correlation coefficient r multiplied by $100 \%$ to find out the amount of contribution the independent variable has in determining the dependent variable. The formula used to decide the degree of determination is as follows:

$$
K D=r^{2} \times 100 \% .
$$

\subsubsection{Path analysis}

This analysis is used to determine the amount of effect of a variable to another variable, both direct influence and joint influence. The immensity of influence of an independent variable to a dependent variable is called path coefficient (Pyx). The relationship structure of these variables can be put into the regression equation, namely:

Sub Structure I: $Y_{1}=P Y_{1} X_{1}+P Y_{1} X_{2}+P Y_{1} X_{3}+P Y_{1} X_{4}+e_{1}$

Sub Structure II : $Y_{2}=P Y_{2} X_{1}+P Y_{2} X_{2}+P Y_{2} X_{3}+P Y_{2} X_{4}+P Y_{2} Y_{2}+e_{2}$

\subsection{Research result}

\subsubsection{Data quality test}

\subsubsection{Validity test}

Based on the data processing result, the validity test result is as follows:

TABLE 1: Validity test.

\begin{tabular}{|c|c|c|c|}
\hline Item Pertanyaan & $\Gamma_{\text {test }}$ & $\mathrm{r}_{\text {table }}$ & Conclusion \\
\hline Compensation 1 & 0.410 & 0.361 & Valid $=r_{\text {hit. }}>r_{\text {tab. }}$ \\
\hline Compensation 2 & 0.614 & 0.361 & Valid $=\mathrm{r}_{\text {hit. }}>\mathrm{r}_{\text {tab. }}$ \\
\hline Compensation 3 & 0.461 & 0.361 & Valid $=r_{h i t .}>r_{t a b .}$ \\
\hline Compensation 4 & 0.811 & 0.361 & Valid $=\mathrm{r}_{\text {hit. }}>\mathrm{r}_{t a b .}$ \\
\hline Compensation 5 & 0.619 & 0.361 & Valid $=\mathrm{r}_{h i t .}>\mathrm{r}_{t a b .}$ \\
\hline Compensation 6 & 0.734 & 0.361 & Valid $=\mathrm{r}_{\text {hit. }}>\mathrm{r}_{t a b .}$ \\
\hline Job Characteristics 1 & 0.638 & 0.361 & Valid $=r_{h i t .}>r_{t a b .}$ \\
\hline Job Characteristics 2 & 0.588 & 0.361 & Valid $=r_{\text {hit. }}>r_{\text {tab. }}$ \\
\hline Job Characteristics 3 & 0.535 & 0.361 & Valid $=r_{\text {hit. }}>r_{t a b .}$ \\
\hline Job Characteristics 4 & 0.501 & 0.361 & Valid $=r_{\text {hit. }}>r_{\text {tab. }}$. \\
\hline Job Characteristics 5 & 0.415 & 0.361 & Valid $=\mathrm{r}_{\text {hit. }}>\mathrm{r}_{\text {tab. }}$. \\
\hline
\end{tabular}




\begin{tabular}{|c|c|c|c|}
\hline Item Pertanyaan & $\mathrm{r}_{\text {test }}$ & $\mathrm{r}_{\text {table }}$ & Conclusion \\
\hline Leadership Style 1 & 0.754 & 0.361 & Valid $=\mathrm{r}_{\text {hit. }}>\mathrm{r}_{\text {tab. }}$ \\
\hline Leadership Style 2 & 0.514 & 0.361 & Valid $=\mathrm{r}_{\text {hit. }}>\mathrm{r}_{\text {tab. }}$ \\
\hline Leadership Style 3 & 0.608 & 0.361 & Valid $=\mathrm{r}_{\text {hit. }}>\mathrm{r}_{\text {tab. }}$ \\
\hline Leadership Style 4 & 0.535 & 0.361 & Valid $=\mathrm{r}_{\text {hit. }}>\mathrm{r}_{t a b .}$ \\
\hline Leadership Style 5 & 0.385 & 0.361 & Valid $=\mathrm{r}_{\text {hit. }}>\mathrm{r}_{\text {tab. }}$ \\
\hline Leadership Style 6 & 0.450 & 0.361 & Valid $=r_{h i t .}>r_{t a b .}$ \\
\hline Motivation 1 & 0.733 & 0.361 & Valid $=\mathrm{r}_{\text {hit. }}>\mathrm{r}_{t a b .}$ \\
\hline Motivation 2 & 0.604 & 0.361 & Valid $=r_{h i t .}>r_{t a b .}$ \\
\hline Motivation 3 & 0.730 & 0.361 & Valid $=\mathrm{r}_{\text {hit. }}>\mathrm{r}_{\text {tab. }}$ \\
\hline Motivation 4 & 0.591 & 0.361 & Valid $=\mathrm{r}_{\text {hit. }}>\mathrm{r}_{t a b .}$ \\
\hline Motivation 5 & 0.478 & 0.361 & Valid $=\mathrm{r}_{\text {hit. }}>\mathrm{r}_{\text {tab. }}$ \\
\hline Employee Performance 1 & 0.536 & 0.361 & Valid $=r_{h i t .}>r_{t a b .}$ \\
\hline Employee Performance 2 & 0.370 & 0.361 & Valid $=r_{\text {hit. }}>r_{t a b .}$ \\
\hline Employee Performance 3 & 0.386 & 0.361 & Valid $=r_{h i t .}>r_{t a b .}$ \\
\hline Employee Performance 4 & 0.568 & 0.361 & Valid $=\mathrm{r}_{\text {hit. }}>\mathrm{r}_{\text {tab. }}$ \\
\hline Employee Performance 5 & 0.543 & 0.361 & Valid $=\mathrm{r}_{\text {hit. }}>\mathrm{r}_{\text {tab. }}$ \\
\hline Employee Performance 6 & 0.548 & 0.361 & Valid $=r_{h i t .}>r_{t a b .}$ \\
\hline Employee Performance 7 & 0.623 & 0.361 & Valid $=\mathrm{r}_{\text {hit. }}>\mathrm{r}_{\text {tab. }}$ \\
\hline
\end{tabular}

Table 1 shows all indicators on each variable have fulfilled the validity requirements, which is $r_{\text {test }}>r_{\text {table }}$. Therefore, these indicators can be used to measure the variables of this study.

\subsubsection{Reliability test}

The reliability test result shows that all variables have fulfilled the reliability test requirements, where the value of Cronbach Alfa test is greater than Cronbach Alpha standard. On that account, it can be concluded that the indicators of variable have an adequate level of consistency to measure these variables.

\subsection{Hypothesis test}

\subsubsection{Substructure I}

The explanation of the study result related to the effect of Compensation, Job Characteristics, and Leadership style to Motivation is as follows:

Influence of compensation on motivation $\left(X_{1} \rightarrow Y_{1}\right)$ 
TABLE 2: Results of Hypothesis Testing of Substructure I.

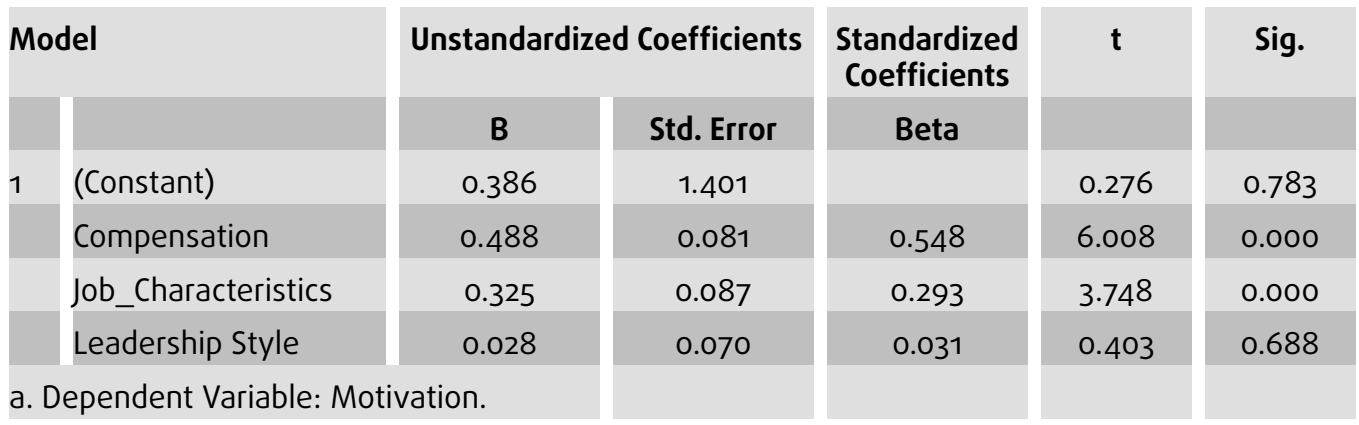

Table 2 shows that the sig value of compensation in this substructure study I is 0.000 . When compared with the alpha value of this study (0.05) it is known that $0.000<0.05$ so it can be concluded that there is an influence of compensation to motivation. The value of the compensation coefficient on motivation is 0.488 .

Influence of job characteristics on motivation $\left(X_{2} \rightarrow Y_{1}\right)$

Table 2 shows that the sig value of job characteristics in this substructure study 1 is 0.000 . When compared with the alpha value of this study (0.05) it is known that $0.000<0.05$ so it can be concluded that there is an influence of job characteristics to motivation. The value of the job characteristics coefficient on motivation is 0.325 .

Influence of leadership style on motivation $\left(X_{3} \rightarrow Y_{1}\right)$

Table 2 shows that the sig value of leadership style in substructure research I is 0.688 . When compared with the alpha value of this study (0.05) it is known that $0.688>$ 0.050 so it can be concluded that there is an insignificant influence of leadership style on motivation. The value of the leadership style coefficient on motivation is 0.028 .

\subsubsection{Substructure II}

The explanation of the study result related to the effect of Compensation, Job Characteristics, and Leadership style to Performance is as follows:

Influence of compensation on performance $\left(X_{1} \rightarrow Y_{2}\right)$

Table 3 shows that the compensation sig value in this sub-structure II study is 0.011 . When compared with alpha value of this study (0.05) it is known that $0.011<0.05$ so it can be concluded that there is influence compensation on performance. The value of compensation coefficient on performance is 0.330 .

Influence of job characteristics on performance $\left(X_{2} \rightarrow Y_{2}\right)$

Table 3 shows that the sig value of job characteristics in this sub-structure II study is 0.002 . When compared with alpha value of this research (0.05) it is known that 0.002 
TABLE 3: Results of Hypothesis Testing of Substructure II.

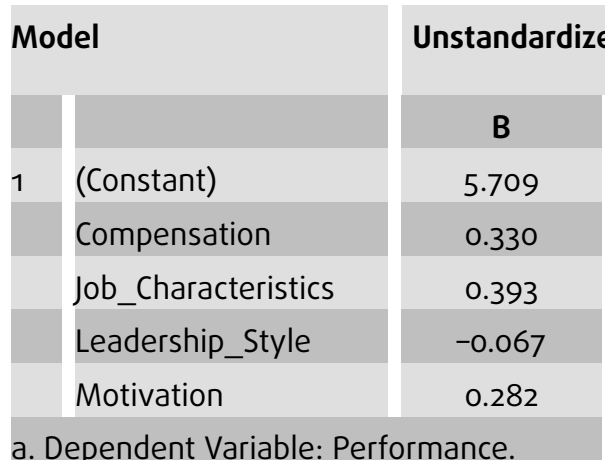

a. Dependent Variable: Performance.

\begin{tabular}{|c|}
\hline Std. Error \\
\hline 1.868 \\
\hline 0.127 \\
\hline 0.123 \\
\hline 0.094 \\
\hline 0.134 \\
\hline
\end{tabular}

\begin{tabular}{|c|}
\hline $\begin{array}{c}\text { Standardized } \\
\text { Coefficients }\end{array}$ \\
\hline Beta \\
\hline \\
\hline 0.310 \\
\hline 0.297 \\
\hline-0.062 \\
\hline 0.236 \\
\hline
\end{tabular}

Sig.

\begin{tabular}{c}
$\mathbf{t}$ \\
\hline 3.057 \\
2.605 \\
3.184 \\
-0.709 \\
2.104
\end{tabular}

0.003

0.011

0.002

0.480

0.038

$<0.05$ so it can be concluded that the characteristics of work affect the performance. The value of job characteristics coefficient on performance is 0.393 .

Influence of leadership style on performance $\left(X_{3} \rightarrow Y_{2}\right)$

Table 3 shows that the sig value of leadership style in sub-structure II research is 0.488 . When compared with alpha value of this study (0.05) it is known that 0.488 $>0.050$ so it can be concluded that there is no significant influence of leadership style on performance. The value of leadership style coefficient on performance is -0.067.

Influence of motivation on performance $\left(Y_{1} \rightarrow Y_{2}\right)$

Table 3 shows that the sig value of motivation in this sub-structure II study is 0.038 . When compared with alpha value of this study (0.05) it is known that $0.038<0.050$ so it can be concluded that there is influence of motivation on performance. The value of leadership style coefficient on performance is -0.067 .

The result of Path Analysis from substructure I and II is as follows:

$$
\begin{gathered}
Y_{1}=0.488 X_{1}+0.325 X_{2}+0.028 X_{3}+0.408 \\
Y_{2}=0.330 X_{1}+0.393 X_{2}--0.067 X_{3}+0.282 Y_{1}+0.504
\end{gathered}
$$

\subsubsection{Substructure II}

1. Influence of Compensation on Performance

The results of this study indicate that the compensation received by employees has an impact on the improvement of employee work performance. This is in accordance with what is stated by Casco in Kartjantoro (2004) which states that compensation as one of the factors needed to assess an employee's performance.

2. Influence of Job Characteristics on Performance 


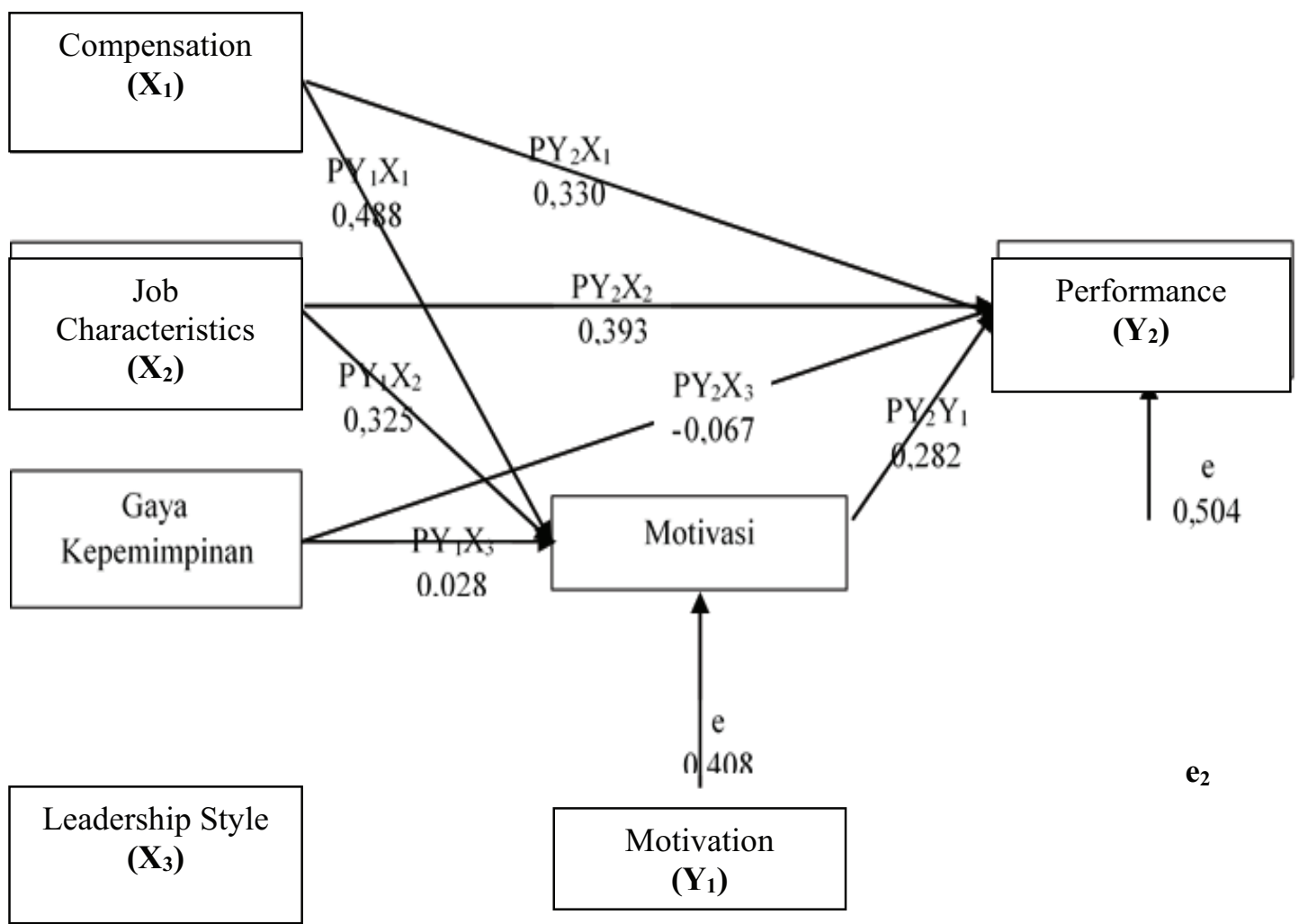

Figure 1: Research Framework and Path Analysis Results.

As an important factor in improving the company's performance, the employee is required to be able to understand and consider the elements of job characteristics, because the characteristics of the work will ideally determine the quality of employee work, it begins with a detailed planning, then carried out to describe the detailed specific of job characteristics that exists on every job. This is in line with that stated by Oldham in Yahya (2009: 2) that job characteristics will greatly contribute to the company when each employee is able to know every characteristic of his work.

3. Influence of Leadership Style on Performance

It is clear that the magnitude of this influence is not dominant compared to other independent variables, this means that when the leadership style changed it will lead to decreased performance of employees. This illustrates that the leadership style applied by the leadership of the company is basically good and favored by all employees in the company.

4. Influence of Motivation on performance

High motivation directly affects performance. Employee motivation should be encouraged to be increased, therefore it should be a concern for the company 
to pay attention to all the needs of its employees. In line with this as stated by As'ad (2004) that motivation is something that raises the spirit or the willingness to work.

\section{Conclusion}

1. There is a significant influence of compensation on motivation at Adolina business unit of PT Perkebunan Nusantara IV. The influence value of compensation on motivation is 0.488 .

2. There is a significant influence of job characteristics on work motivation of employees at Adolina business unit of PT. Perkebunan Nusantara IV. The influence value of job characteristics on motivation is 0.325 .

3. There is no significant influence of leadership style on work motivation of employees at Adolina business unit of PT. Perkebunan Nusantara IV. The influence value of leadership style on motivation is 0.028 .

4. There is a significant influence of compensation on employee performance at Adolina business unit of PT. Perkebunan Nusantara IV. The influence value of compensation on performance is 0.330 .

5. There is a significant influence of job characteristics on employee performance at Adolina business unit of PT. Perkebunan Nusantara IV. The influence value of job characteristics on performance is 0,393 .

6. There is no significant influence of leadership style on employee performance at Adolina business unit of PT. Perkebunan Nusantara IV. The influence value of leadership style on performance is -0.067 .

7. There is a significant influence of motivation on employee performance at Adolina business unit of PT. Perkebunan Nusantara IV. The influence value of motivation on performance is 0.282 .

\section{Acknowledgement}

The author would like to express his gratitude to Dr. Harmein Nasution, for sharing his pearl of wisdom during this research. He is also immensely grateful to Dr. Nazaruddin Matondang, for providing assistance with his research methodology and comments 
that greatly improved this research. The author would like to thank Dr. Amrin Fauzi, Dr. Isfenti Sadalia, and Dr. Iskandarini, for reviewing the article with their so-called insights.

\section{References}

[1] Prayatna, A. H. and Subudi, M. (2016). Pengaruh Gaya Kepemimpinan Terhadap Stress Kerja dan Kepuasan Kerja Karyawan Pada Fave Hotel Seminyak. E-Journal Management Unud, vol. 5, no. 2, pp. 845-872.

[2] Syamsul, A. (2012). Leadership Ilmu dan Seni Kepemimpinan. Jakarta: Mitra Wacana Media.

[3] Arikunto, S. (2010). Manajemen Penelitian. Jakarta: Rhineka Cipta.

[4] Asmawar, M. and Yunus, A. (2014). Pengaruh Kompensasi dan Pengawasan Pimpinan Terhadap Disiplin dan Dampaknya Pada Peningkatan Kinerja Pegawai Negeri Sipil Dinas Kesehatan Kabupaten Aceh Jaya. Management Journal of Syiah, Kuala University Postgraduate, vol. 3, no. 1, pp. 10-16.

[5] Davis, K. (2010). Organizational Behavior - Human Behavior at Work (thirteenth edition). New Delhi: Mc. Graw Hill Company.

[6] Merysca, D. A. (2013). Analisis Pengaruh Lingkungan Kerja, Kompensasi, dan Program Pengembangan Terhadap Kinerja Karyawan Melalui Motivasi Kerja Pada PT Bank CIMB Niaga, Tbk Cabang Jember. Jember University Journal, Jember.

[7] Arifah, D. A. and Romadhon, C. (2015). Pengaruh Komitmen Organisasi, Komitmen Profesional dan Gaya Kepemimpinan Terhadap Kepuasan Kerja Dengan Motivasi Sebagai Variabel Intervening, Studi Empiris pada Kantor Akuntan Publik di Semarang). Conference in Business, Accounting and Management, vol. 2, no. 1, pp. 357-369.

[8] Fried, Y., and Ferris, G. R. (1987). The Validity of the job characteristics model: A Review and Meta-Analysis. Personnel Psychology, vol. 40, pp. 297-322.

[9] Gardjito, A. H., Musadieq, M. A., and Nurtjahjono, G. E. (2014). Pengaruh Motivasi Kerja dan Lingkungan Kerja Terhadap Kinerja Karyawan (Studi pada Karyawan Bagian Produksi PT Karmand Mitra Andalan Surabaya). Business Administration Journal (BAJ), vol. 13, no. 1.

[10] Hadari, H. N. (2010). Manajemen Sumber Daya Manusia untuk Bisnis yang Kompetitif. Yogyakarta: Gajah Mada University Press.

[11] Handoko, T. H. (2011). Manajemen Personalia Dan Sumber Daya Manusia (second edition). Yogyakarta: BPFE. 
[12] Hasibuan, M. (2014). Manajemen Sumber Daya Manusia (Edisi Revisi). Jakarta: Bumi Aksara.

[13] Hita, Y. G., Pradhanawati, A., and Hidayat, W. (2013). Pengaruh Kompensasi dan Disiplin Kerja Terhadap Kinerja Karyawan Dengan Motivasi Sebagai Intervening Variabel Pada Perum Perhutani Unit 1 Jawa Tengah. Business Administration Journal, vol. 2, no. 2, pp. 1-12.

[14] Ghozali, I. (2013). Aplikasi Analisis Multivariate Dengan Program SPSS Edisi Ketujuh. Semarang: Diponegoro University.

[15] Djastuti, I. (2011). Pengaruh Karakteristik Pekerjaan Terhadap Komitmen Organisasi Karyawan Tingkat Managerial Perusahaan Jasa Konstruksi di Jawa Tengah. Account and Business Journal, vol. 13, no. 1, pp. 1-19.

[16] Jackson, S. E., Schuler, R. S., and Werner, S. (2011). Pengelolaan Sumber Daya Manusia (tenth edition). Jakarta: Salemba Empat.

[17] Kartjantoro, H. (2012). Manajemen Sumber Daya Manusia. Yogyakarta: BPFE.

[18] Kuncoro, M. (2009). Metode Riset Untuk Bisnis dan Ekonomi. Jakarta: Erlangga.

[19] Mangkunegara, A. P. (2012). Manajemen Sumber Daya Manusia. Bandung: Remaja Rosdakarya.

[20] Manullang, M. (2010). Dasar-dasar Manajemen. Jakarta: Salemba Empat.

[21] Mathis, R. L. and Jackson, J. H. (2012). Manajemen Sumber Daya Manusia (first edition). Jakarta: Salemba Empat.

[22] Moekijat. (2010). Sumber Daya Manusia. Bandung: CV. Mandar Maju.

[23] Mondy, R. W. and Noe R. M. (2005). Human Resource Management (ninth edition). Massachusetts: Prentice Hall.

[24] Akhtar, N., Zahid Hussain, S. A., and Muhammad Salman, S. A. (2014). Factor affecting employees motivation in banking sector of Pakistan. Journal of Asion Business Strategy, vol. 4, no. 10, pp. 125-133.

[25] Panggabean, S. M. (2010). Manajemen Sumber Daya Manusia. Jakarta: Ghalia Indonesia.

[26] Panudju, A. (2003). Pengaruh Kompensasi dan Karakteristik Pekerjaan Terhadap Kepuasan Kerja Karyawan Unit PT. X Palembang. Sriwijaya Management and Business Journal.

[27] Ranupandojo, H. (2012). Manajemen Personalia. Yogyakarta: BPFE Gajah Mada.

[28] Robbins, S. P. and Coulter, M. (2010). Management (tenth edition). Jakarta: PT. Erlangga.

[29] Siagian, S. P. (2001). Manajemen Sumber Daya Manusia. Jakarta: Bumi Aksara. 
[30] Sinulingga, S. (2013). Metodologi Penelition. Medan: USU Press.

[31] Sopiah. (2008). Perilaku Organisasional. Malang: Andi.

[32] Richard, S. M. (1985). Efektivitas Organisasi Perusahaan. Jakarta: Erlangga.

[33] Subanegara, H. P. (2010). Modul Rencana Strategi Bisnis. Solo: Penerbit Public Consult.

[34] Sugiyono. (2013). Metode Penelitian Kualitatif dan Kualitatif (revision edition). Bandung: Alfabeta.

[35] Sutrisno, E. (2010). Manajemen Sumber Daya Manusia. Jakarta: Kencana Prenada Media Group.

[36] Thoha, M. (2013). Kepemimpinan dalam Manajemen (thirteenth edition). Jakarta: Raja Grafindo Persada.

[37] Siddiq, U. (2014). Organisasi Pembelajaran Pada Pondok Pesantren di Era Global. Cendekia, vol. 12, no. 1, pp. 121-138.

[38] Rahayu, V. T. (2013). Pengaruh Kepemimpinan, Lingkungan Kerja Fisik, dan Kompensasi Terhadap Kinerja Karyawan di PT PLN Cabang Madiun. Account and Management Research Journal, vol. 1, no. 1, pp. 89-95.

[39] Veithzal, R. Z. (2014). Manajemen Sumber Daya Manusia Untuk Perusahaan: Dari Teori Ke Praktik. Depok: Publisher Rajagrafindo Persada. 